\title{
Financial Statement Fraud and the Failure of Corporate Financial Statement Fraud Prediction
}

\author{
Wm. Dennis Huber \\ Nova Southeastern University \\ James A. DiGabriele \\ Montclair State University
}

There have been many advances in recent years in accounting literature that focus on theories for detecting the occurrence of corporate financial statement fraud. Many tools and methods have been developed to detect the occurrence of corporate financial statement fraud, particularly using various computer-assisted auditing tools including artificial intelligence. However, there is also within the accounting literature a stream of research that focuses on theories and models attempting to predict the occurrence of corporate financial statement fraud. This paper examines those theories and models and explains why those theories and models fail to predict the occurrence of corporate financial statement fraud.

Keywords: financial statement fraud, fraud prediction

\section{INTRODUCTION}

Fraud occurs in many situations ranging from the sale of used cars to the sale of stocks and bonds; from obtaining a bank loan to obtaining insurance payments; from using the U.S. mail to corporations issuing financial statements. This paper focuses on fraudulent corporate financial statements, a global, multi-billion dollar per year phenomenon, and models and theories that attempt to predict the occurrence of corporate financial statement fraud, and explains why attempts to predict the occurrence of corporate financial statement fraud fail.

The importance of the paper is to demonstrate that models and theories that purport to predict the occurrence of financial statement fraud are at best misguided. They detract from the need to focus on research for improving methods of detecting the occurrence of corporate financial statement fraud. Hopefully, this paper will redirect research away from something that is impossible - predicting corporate financial statement fraud - to more useful and relevant research - better methods of detecting and preventing corporate financial statement fraud.

There are dozens of examples of corporations issuing fraudulent financial statements. Perhaps the most well-known is that of Enron which resulted in Congress enacting the Sarbanes-Oxley Act of 2002. (Green, 2004) The Corporate Finance Institute lists the "Top Accounting Scandals" many of which occurred during the first decade of the twenty-first century including Waste Management. Enron, WorldCom, Tyco, HealthSouth, Freddie Mac, American International Group, Lehman Brothers, and Satyam an Indian company. ${ }^{1}$ Also in 2004, the founder of Parmalat, an Italian company, was sentenced to 18 years in prison 
for corporate fraud. ${ }^{2}$ More recently, AccountingAge lists the "Top accounting scandals in 2018" including Carillion, Patisserie Valerie, Ted Baker, BHS, Gupta, and GE. ${ }^{3}$ In June, 2020 the New York Post reported Wirecard's CEO Markus Braun resigned amid accusations of a $\$ 2$ billion fraud. ${ }^{4}$

However, corporate financial statement fraud is not actually committed by the corporations that issue the financial statements. Corporate financial statement fraud is committed by individuals within the corporation such as the president, CEO, or CFO, among others. ${ }^{5}$ For example, in 2004 Andrew Fastow entered a plea of guilty in federal court to charges of securities fraud in relation to Enron's fraudulent financial statements ${ }^{6}$ and Markus Braun resigning from Wirecard.

This paper reviews theories and models that attempt to explain why individuals commit corporate financial statement fraud, and theories and models that purport to predict the occurrence of corporate financial statement fraud. Our purpose is limited first to establishing that theories and models that attempt to explain why individuals commit corporate financial statement fraud, and second to explain why theories and models that attempt to explain why individuals commit corporate financial statement fraud, cannot be transformed into theories and models that can predict the occurrence of corporate financial statement fraud. Our goal is to divert research away from attempts to predict the occurrence of corporate financial statement fraud into more relevant and meaningful research that can detect the occurrence of corporate financial statement fraud.

The rest of the paper is organized as follows. First, we present the legal definition of fraud and the elements that must be proven in a court of law to obtain a civil judgment or criminal conviction of fraud. We then review theories and models that attempt to explain why individuals commit corporate financial statement fraud, which we classify as behavioral/explanatory, in order to demonstrate that contrary to the accounting literature, theories and models that attempt to explain why individuals commit corporate financial statement fraud cannot be used to predict the occurrence of corporate financial statement fraud.

An important consideration in the use of theories and models that attempt to explain why individuals commit corporate financial statement fraud to predict corporate financial statement fraud is the institutional recognition of behavioral/explanatory models (e.g., the AICPA). Institutional recognition of theories and models that attempt to explain why individuals commit corporate financial statement fraud to predict financial statement fraud has bestowed unwarranted authoritative support for the use of behavioral/explanatory models that attempt to predict the occurrence corporate financial statement fraud.

Third, we explain that, apart from not being able to use behavioral/explanatory theories and models that attempt to explain why individuals commit corporate financial statement fraud to predict the occurrence of corporate financial statement fraud, behavioral/explanatory theories and models that attempt to explain why individuals commit corporate financial statement do not actually explain why individuals commit corporate financial statement fraud. If behavioral/explanatory models of corporate financial statement fraud cannot actually explain why individuals commit corporate financial statement fraud, they cannot be used to predict the occurrence of corporate financial statement fraud.

We next present a review of corporate financial statement fraud prediction theories and models which, in addition to behavioral/explanatory models that are used to predict the occurrence of corporate financial statement fraud, include empirical/quantitative theories and models. Our purpose is limited to establishing that models that purport to predict the occurrence of financial statement fraud do not and cannot predict the occurrence of corporate financial statement fraud. Our intent is to re-channel research into more productive areas for detecting the occurrence of financial statement fraud. As with institutional recognition of behavioral/explanatory models of why individuals commit corporate financial statement fraud, institutional recognition of theories and models that purport to predict the occurrence of corporate financial statement fraud is also an important consideration since it lends unwarranted authoritative support for the use of empirical/quantitative models to predict the occurrence of corporate financial statement fraud.

We then evaluate theories and models used in predicting the occurrence of corporate financial statement fraud and explain why they fail to predict the occurrence of corporate financial statement fraud.

Conclusions follow. 


\section{FRAUD}

The term "fraud" is often used colloquially or informally to refer to crimes or torts that are not actually fraud. Embezzlement by employees, for example, is frequently referred to as "employee fraud."

However, fraud is a legal term that has a precise and exact legal meaning that encompasses both civil and criminal aspects. It is not just a question of semantics, but is of the utmost importance for establishing whether fraud has actually occurred. An employee, for example, cannot be charged with fraud when the employee commits an act of embezzlement. To call employee embezzlement fraud is indefensible. Fraud is defined as

"the intentional misrepresentation of a material fact made for the purpose of inducing another to rely, and on which the other reasonably relies to his or her detriment. 'Fraud' consists in deception practiced in order to induce another to part with property or surrender some legal right and which accomplishes the end designed. The tort of fraud is defined as the willful misrepresentation of a material fact, made to induce another to act, upon which such person acts to his or her injury; an essential element in every fraud action is a finding that the representation was made with the intention and purpose of deceiving the opposite party and for the purpose of injuring him or her."7

In other words, one must make an untrue statement of fact knowing the statement is untrue, or lacking reasonable grounds for believing it to be true, with the intent that a second person relies on the untrue statement, for the purpose of obtaining the property or property rights of the second person which results in harm to the second person. ${ }^{8}$ The statement may be either oral or written. The second person is not aware at the time that the statement is untrue. The victim discovers it later.

Fraud is a specific intent crime or civil tort, which means that every element of fraud must be proven in a court of law in order to obtain a civil judgment or criminal conviction. If any element is missing, there is no fraud. Only a trier of fact, usually a jury, can decide whether a defendant has committed fraud. While there are fraud examiners and fraud auditors, they may not make a factual determination whether fraud has been committed. They may only present evidence to the trier of fact who determines whether the evidence sustains the allegation that fraud has been committed.

In a case of corporate financial statement fraud, for example, a fraud examiner may testify in court that a corporation's net income is overstated by twenty-five percent. The fraud examiner is not permitted by the court to testify that the financial statements are fraudulent because the net income of the corporation is overstated by twenty-five percent. Only the trier of fact, weighing all the evidence, may make such a determination. But the corporation is not the defendant. The CEO or CFO is the defendant as demonstrated by Andrew Fastow's plea of guilty to securities fraud. ${ }^{9}$

The basis of criminal fraud is statutory. That is, fraud that constitutes a crime arises only when a person commits an act that is defined by federal or state statutes as fraud. The statute that defines a particular fraud is accompanied by criminal penalties such as fines or imprisonment. Intentionally making untrue statements in corporate financial statements is a federal crime punishable by fines and imprisonment, again as demonstrated by Andrew Fastow's plea of guilty to securities fraud.

Civil fraud has no criminal penalties such as fines or imprisonment. However, the plaintiff must still prove every element of fraud to the trier of fact, and the plaintiff is awarded monetary damages if the trier of fact determines that the defendant committed fraud.

Whether civil or criminal, however, fraud always concerns statements that were made by the defendant in the past and relied upon by the victim in the past. The financial statements of a corporation that overstates its net income by $25 \%$ is a statement made in the past, e.g., the previous year. The civil judgement or criminal conviction is based on statements made by the defendant in the past.

Psychologists, psychiatrists, and criminologist may delve into the psyche of individuals who commit corporate financial statement fraud, i.e., their motive, just as they do for any other crime. They may develop theories and models of why individuals commit corporate financial statement fraud and create profiles of 
those who commit corporate financial statement fraud, generally referred to as "fraudsters," which can aid in understanding why people commit corporate financial statement fraud. Yet understanding why individuals committed corporate financial statement fraud in the past is not equivalent to predicting the occurrence of corporate financial statement fraud.

The following section discusses theories and models that attempt to explain why individuals commit corporate financial statement fraud.

\section{MODELS OF FRAUD}

\section{Theories and Models of Fraud}

First, it should be noted that this paper uses the term "theories and models" of fraud. Although not synonymous they are inseparable. Theories of corporate financial statement fraud cannot be isolated from models of corporate financial statement fraud as the terms are used in the literature.

Singleton and Singleton (2010) remark that fraud auditors must be able to identify possible fraud schemes, which they refer to as the "fraud theory approach." They go on to state fraud "encompasses a theory structured around motive, opportunity, and rationalization (the 'fraud triangle')." Thus, according to Singleton and Singleton, a theory of fraud is a function of a model of fraud. Dorminey, Fleming, Kranacher, and Riley (2012) agree, stating, "Cressey $(1950,1953)$ hypothesized that for fraud to occur, each of the three criteria must be present: perceived pressure, perceived opportunity, and rationalization. One representation of his theory...evolved into what we know today as the 'Fraud Triangle."”

Van Akkeren (2018) explains, "There has been much attention on explaining causes of fraud based around the 'Fraud triangle,' the original theory developed by Donald Cressey in 1953..."

Ruankaew (2016) equates the fraud triangle model with the fraud triangle theory:

"The fraud triangle theory is well-known and is often discussed in the literature. However, later an expanded version of the fraud triangle theory, the fraud diamond theory, was introduced. The fraud diamond theory offers insightful information regarding the various factors that have an impact on an individual's decision to commit fraud." (p. 474).

Dorminey, Fleming, Kranacher, and Riley (2012) attempt to "unify many of the existing theories on fraud" by presenting "a meta-model for fraud theory" and providing "an overview of fraud, the foundations of fraud theory, and a simple model of fraud, followed by the well-known Fraud Triangle."

\section{Behavioral and Explanatory Models of Fraud}

Several behavioral/explanatory models have been proposed to explain the reasons why individuals commit corporate financial statement fraud, all conveniently reduced to geometric shapes. As the term implies, behavioral/explanatory models attempt to explain why individuals commit corporate financial statement fraud are based in large part on some innate behavioral trait of individuals who commit the fraud. Unfortunately, behavioral/explanatory models of fraud are not actually related to fraud. (Huber, 2017)

\section{Fraud Triangle}

Most of the previous research explaining why individuals corporate financial statement fraud uses the fraud triangle/ (Brazel et al., 2009) The fraud triangle is built on Cressey's (1953) theory of why individuals commit embezzlement - perceived pressure, opportunity, and rationalization. The fraud triangle theory was then extended to corporate financial statement fraud.

Free, Macintosh, and Stein (2007) created an "organizational fraud triangle" to explain why fraud occurs. The organizational fraud triangle consists of the corporation's organizational leadership, organizational culture and management control systems. 


\section{Fraud Diamond}

Wolfe and Hermanson (2004) expanded the fraud triangle by adding the element of capability to the fraud triangle, thus forming a diamond. Capability is a function of organizational position, appropriate expertise, confidence or ego, ability to coerce others to participate in fraudulent activities, ability to deal with stress, and being a good liar.

\section{Fraud Square}

Societal influences have been proposed by Cieslewicz $(2010,2012)$ as a fourth factor, changing the fraud triangle into a fraud square, as opposed to the fraud diamond which added capability. Societal influences account for international differences in culture as identified by Hofstede and how the differences relate to explaining why individuals commit fraud.

\section{Fraud Pentagon}

Marks (2012) adds arrogance and competence to the fraud triangle to form a fraud pentagon. Competence is the ability of a person to commit fraud. Arrogance is a person's disregard of corporate policy and belief that procedures do not apply to her. Pamungkas and Utomo (2018) incorporate the fraud pentagon theory, for example, in Southeast Asian nations' corporate governance scorecard.

\section{Institutional Recognition of Behavioral/Explanatory Models}

The American Institute of Certified Public Accountants (AICPA) recognizes the elements of the fraud triangle in its official publications, although it does not use the term "fraud triangle."

"Separately presented are examples relating to the two types of fraud relevant to the auditor's consideration - that is, fraudulent financial reporting and misappropriation of assets. For each of these types of fraud, the risk factors are further classified based on the three conditions generally present when material misstatements due to fraud occur: (a) incentives/pressures, (b) opportunities, and (c) attitudes/rationalizations" (AICPA, 2002).

The AICPA does not officially recognize any other "geometric" model of fraud.

The Association of Certified Fraud Examiners (ACFE) also recognizes the fraud triangle in its official publications. In fact, the ACFE was established on the premise of the fraud triangle (ACFE, 2016; Huber, 2017). In explaining why fraud occurs the ACFE states, "The best and most widely accepted model for explaining why people commit fraud is the fraud triangle. This is a model developed by Dr. Donald Cressey, a criminologist whose research focused on embezzlers - people he called "trust violators"' (ACFE, nd,a, emphasis added).

The ACFE does not officially recognize any other "geometric" model of fraud.

\section{The Irrationality of Fraud Models}

Behavioral/explanatory models of fraud are irrational. All behavioral/explanatory models are based on Cressey's Other People's Money: A Study in the Social Psychology of Embezzlement published in 1953. Embezzlement is another specific intent crime defined as "a criminal breach of trust that violates a fiduciary relationship." 10 Cressey's study of embezzlers is actually an "embezzlement triangle," not a fraud triangle (Huber, 2017).

As explained above, the fraud triangle is based on incentive, opportunity, and rationalization which are Cressey's explanations for why people embezzle. The fraud diamond and fraud square merely add additional elements to the fraud triangle. Others are merely synonyms for the labels of the fraud triangle or change the labels of the points of the triangle to the sides of the triangle.

But, as explained by Huber (2017), the fraud triangle and other geometric behavioral/ explanatory models of fraud are irrational because they have nothing to do with fraud. The legal elements of fraud require the intentional misstatement of a material fact, reliance on the misstated facts by a second party 
resulting in damage or injury to the second party such as the transfer of property or property rights to the person making the representation.

The distinction is that embezzlement is a breach of trust that pertains to the intentional taking for personal use the property of another that one already possesses, or has access to or control over, with knowledge that the property belongs to the other person. Fraud pertains not to the taking of the property of another that one already possesses, or has access to or control over, but to attempts to acquire the property or property rights of another that one does not already possess, or has access to or control over. Thus behavioral/explanatory models of fraud do not actually explain fraud. Cressey had nothing to say about fraud. His theory was only based on embezzlement. (See Huber, 2017.)

The recognition of the fraud triangle in official publications and representatives of such international institutions such as the AICPA and ACFE demonstrates the extent to which the fraud triangle has permeated what is known as "fraud theory."

Behavioral/explanatory models of fraud have been expanded into fraud prediction models. In addition, empirical/quantitative models have been developed in attempts to predict fraud.

\section{FRAUD PREDICTION MODELS}

\section{The definition of "predict" is}

"to declare or indicate in advance; especially: foretell on the basis of observation, experience, or scientific reason." 11

While behavioral/explanatory models attempt to explain why individuals commit fraud, behavioral/ explanatory models have also been used to predict the occurrence of fraud. In addition, empirical/quantitative models have been developed that attempt to predict the occurrence of fraud. "Predictive or forward looking models" include "predictive data analyses [using] data mining, statistical modeling, machine learning and artificial intelligence to develop intelligent scorecards and powerful business rules, which enables prediction of potential fraudulent activity with a reasonable degree of probability" (Lai \& Khashu, 2015, p. 73, emphases added).

Bauguess (2017) comments that "it is more challenging for machine learning algorithms to make accurate predictions of possible fraud... When new data arrives, the trained 'machine' predicts the current likelihood of possible fraud on the basis of what it learned constituted possible fraud from past data" (emphasis added).

If one were to accept the ACFE's definition of fraud, "In the broadest sense, fraud can encompass any crime for gain that uses deception as its principal modus operandus" (ACFE, nd,a) one would be tempted to classify any article that argues that fraud prediction models can actually predict fraud is itself fraudulent, except that, although the gain is there in terms of recognition for the publication, such arguments are not crimes or torts. But still, such arguments are deceptive to the public and to researchers.

The so-called "elite" accounting journals are not immune to publishing articles that advance models of fraud prediction. Dechow, Ge, Larson, and Sloan (2011), for example, published "Predicting Material Accounting Misstatements" in Contemporary Accounting Research. The Accounting Review published Perols, Bowen, Zimmermann, and Sambas (2017) "Finding Needles in a Haystack: Using Data Analytics to Improve Fraud Prediction." Brazel, Jones, and Zimbelman (2009) published "Using Nonfinancial Measures to Assess Fraud Risk" in Journal of Accounting Research which, "add[s] to this literature by exploring whether a new category of variables - namely, NFMs - can add discriminatory power to fraud prediction models developed from prior research" (p. 1137, emphasis added).

Others include Bell and Carcello's (2000), "Research Notes, A decision aid for assessing the likelihood of fraudulent financial reporting," published by the American Accounting Association's Auditing: A Journal of Theory and Practice, and Omar, Johari, and Smith's (2017) "Predicting fraudulent financial reporting using artificial neural network," published by the Journal of Financial Crime. The SEC, AICPA, and ACFE have all embraced in various manners fraud prediction models, as explained below. 
Models attempting to predict fraud are not limited to U.S. research. For example, Lai and Khashu (2015) advocate forensic data analysis (FDA) as an effective mechanism to manage the risk of fraud. FDA uses both structured and unstructured data sources "for detecting and, in some cases, predicting fraud with a high degree of probability" (p. 67, emphasis added). They further suggest that certain strategies could "assist in real-time detection of and predicting potential fraudulent behaviour" (p. 70, emphasis added).

While most fraud prediction models are empirical/quantitative, behavioral/explanatory models have also been used to predict fraud.

\section{Behavioral/Explanatory Models Used in Fraud Prediction}

While behavioral/explanatory models of fraud are not themselves empirical or quantitative, and while the validity of behavioral/explanatory models of fraud have not been tested empirically (e.g., Indarto \& Ghozali, 2016; Boyle, DeZoort, \& Hermanson, 2015), they have nevertheless been used as models of fraud prediction.

Skousen, Smith, and Wright (2009) "develop variables which serve as proxy measures for pressure, opportunity, and rationalization and test these variables using publicly available information" for predicting fraud in corporate financial statements. Roden, Cox, and Kim (2016) attempt to quantify pressure, opportunity, and rationalization of the fraud triangle using logistic regression while controlling for the size, leverage, and profitability of the corporation.

It must be remembered, however, that although their articles are titled "Detecting and Predicting Financial Statement Fraud: The Effectiveness of the Fraud Triangle and SAS No. 99," and "The Fraud Triangle as a Predictor of Corporate Fraud," respectively, corporations cannot commit fraud because fraud is a function of intent and corporations cannot form intent.

\section{Empirical/Quantitative Models Used in Fraud Prediction}

The goal of the scientific research method is to make predictions based on testable hypotheses and empirical evidence. "It may be self-evident that central objectives of empirical research should be to make predictions..." (Manski, 2008, p. 6, emphasis added). Researchers often test a hypothesis and predict that they will find evidence to support or refute the hypothesis, such as predicting the future movement of an astronomical body, or predict future stock prices using past stock prices.

The F-Score was created to help identify companies that could potentially outperform the stock market, but was converted into the Fraud Score used to assess companies for potential fraud (Harris, 2015). Baesens, Van Vlasselaer, and Verbeke (2015) devote an entire chapter to "predictive analytics for fraud detection" using "linear regression, logistic regression, decision trees, neural networks, support vector machines, ensemble methods, and multiclass classification techniques." Lai and Khashu (2015) advocate forensic data analysis to detect predict fraud.

Albrecht (nd) suggests a fraud hypothesis testing approach which allows auditors to gain "a solid understanding of the business processes, controls, and environment. This understanding allows them to proactively predict the frauds that might be occurring" (emphasis added).

A popular empirical/quantitative method for detecting fraud in financial statements is ratio analysis, or what auditors refer to as "analytical procedures." For example, Skousen and Wright (2006) acknowledge that "in any given fraud, multiple risk factors are typically present" (p. 20). They identified "a comprehensive set of coexistent factors that are consistently linked to the incidence of financial statement fraud" (p. 20). Those risk factors included various financial statement ratios such financial stability and profitability ratios and leverage ratios. However, they extend those factors "to construct a robust fraud prediction model" (p. 2, emphasis added). ${ }^{12}$

Somewhat strange, a U.S. patent was granted for an empirical/quantitative fraud prediction model. In 2001 HNC Software, Inc. was granted a patent for "Mechanism and method for continuous operation of a rule server" for "An automated system and method [that] detects fraudulent transactions using a predictive model such as a neural network to evaluate individual customer accounts and identify potentially fraudulent transactions based on learned relationships among known variables." ${ }^{\prime 3}$ While not a model for predicting fraudulent financial statements, it is worthy to include it here to demonstrate the extent to which researchers 
will attempt to predict future fraud, and since the patent involves neural networks, it is intricately related to neural network models used to predict fraudulent financial statements.

\section{Institutional Recognition of Fraud Prediction Models}

Institutional recognition of corporate financial statement fraud prediction models are seen in official publications or other acknowledgements by the institutions or by individuals representing the institutions. For example, in a recent speech, Scott W. Bauguess, Acting Director, Division of Economic and Risk Analysis of the SEC stated, "When new data arrives, the trained 'machine' predicts the current likelihood of possible fraud on the basis of what it learned constituted possible fraud from past data." (Bauguess, 2017)

The AICPA (nd) introduced a simplified version of a corporate financial statement fraud prediction model created by Lee, Churyk, and Clinton (2013) which is based on content analysis.

The ACFE published a White Paper in its official Fraud Magazine "Analytics in compliance: Using predictive analytics to proactively identify compliance risks in transactions." (ACFE nd,b) According to the White Paper, "Predictive analytics can indicate where misconduct may occur by analysing [sic] a company's sales...finance (accounts payable/receivable, expense claims)...[and] operations (inventory management)...data (emphasis added)." While not explicitly referring financial statement fraud ,obviously sales, expenses, and inventory are directly related to financial statements. But the point to note here is the assertion that "predictive analytics can indicate where misconduct may occur."

\section{Evaluation of Fraud Prediction}

"[F]raud is neither very visible nor easily predictable." (Morales, Gendron, \& GuéninParacini, 2014, p. 191)

In evaluating models of corporate financial statement fraud prediction, we must also consider "predication." Predication is the noun form of "predicate," a transitive verb meaning "to proclaim; declare; affirm; assert." 14

According to Kranacher, Riley, and Wells (2011)

"Predication is the totality of circumstances that lead a reasonable, professionally trained and prudent individual to believe that a fraud has occurred, is occurring, and/or will occur. All fraud examinations must be based on proper predication..." (p. 32, emphasis added).

Likewise, Albrecht, et al (2015) echo the same sentiments.

"Predication is the totality of circumstances that lead a reasonable, professionally trained and prudent individual to believe that a fraud has occurred, is occurring, and/or will occur. Fraud examinations should not be conducted without predication..." (p. 80 emphasis added).

There are several problems that are evident in the above quotes. First, one cannot proclaim, declare, affirm, or assert that fraud will occur since whether fraud will occur in the future is a prediction that is dependent on the state of mind and intent of individuals which cannot be predicted. Second, one cannot proclaim, declare, affirm, or assert that fraud has occurred until after evidence is obtained to support the declaration.

Third, whether fraud has occurred can only be determined by a court of law by the trier of fact (i.e., the jury). A fraud investigator is prohibited from forming an opinion as to whether fraud has occurred. The task of a fraud investigator is only to obtain evidence to present to the court.

It must be recognized that absolutely no theory or model of fraud-behavioral/ explanatory or empirical/ quantitative - has ever succeeded in predicting corporate financial statement fraud and in fact is 
not capable of predicting corporate financial statement fraud not only because predicting fraud requires predicting the future, but because fraud involves states of mind which are inherently unpredictable.

Prediction, by definition, involves the future. Fraud, by definition, is an event that occurred in the past. A criminal defendant is convicted for committing fraud in the past, not for what she intends to do in the future. A researcher may only predict that evidence will show that corporate financial statement fraud occurred in the past. She cannot predict the occurrence of corporate financial statement fraud.

\section{CONCLUSION}

Fraud, by definition, requires a specific state of mind of an individual regarding a specific even that occurred in the past. Fraud requires a false statement made by an individual knowing it is false with the intent to acquire the property or property rights of another and the other person relies on the false statement to his or her injury. Likewise, "predict" has a precise scientific meaning. To predict can only refer either to the occurrence of a future event, or to the detection of an event. A state of mind cannot be predicted.

Since fraud has a precise legal meaning, only the precise legal meaning should be used by accounting researchers. The non-legal usage of the terms in accounting research is unacceptable. These are not merely semantic differences.

To use "fraud" in accounting research to mean anything other than its precise legal definition is misguided. Similarly, a model that purports to predict the occurrence of corporate financial statement fraud is merely a tool to detect whether fraud has occurred in the past. For accounting researchers to say "predicting" corporate financial statement fraud when what they are actually referring to is "detecting" corporate financial statement fraud is misleading.

To predict corporate financial statement fraud means you are predicting a state of mind - the intent of a person. Since fraud can only be committed by individuals, alone or in collusion, that would be tantamount to saying, "I predict that next year the CEO will commit financial statement fraud," thus relegating fraud prediction to a "minority report.". It simply cannot be done. If fraud could be predicted, a company would simply not hire, or would fire if already employed, the suspected perpetrator.

There is no accounting research that has demonstrated that it is capable of predicting corporate financial statement fraud, while much accounting research has demonstrated that it is capable of detecting corporate financial statement fraud. There is no theory or model that is capable of predicting corporate financial statement fraud. It is and has been a waste of time and resources. It would therefore behoove accounting researchers to abandon attempts to predict the occurrence of corporate financial statement fraud or to create a theory of corporate financial statement fraud prediction. Accounting researchers should cease referring to corporate financial statement fraud prediction. Instead, researcher should concentrate on developing better methods to detect the occurrence of corporate financial statement fraud which can in turn lead to better methods to prevent the occurrence of corporate financial statement fraud.

\section{ENDNOTES}

1. "Top Accounting Scandals." Accounting Scandals - List of Top 10 Scandals in Past Decades (corporatefinanceinstitute.com).

2. “Parmalat founder sentenced in company's collapse.” Parmalat founder sentenced in company's collapse | Reuters

3. “Top accounting scandals in 2018." Top accounting scandals in 2018 (accountancyage.com).

4. "Wirecard CEO quits amid allegations of fraud over missing \$2B.” Wirecard CEO Markus Braun quits amid fraud allegations, missing \$2B (nypost.com).

5. Corporations, being fictitious persons, or course cannot commit financial statement fraud since fraud requires intent and corporations cannot form intent. It is individuals within a corporation that commit fraud since only individuals can form intent.

6. "Andrew S. Fastow, Former Enron Chief Financial Officer, Pleads Guilty, Settles Civil Fraud Charges and Agrees to Cooperate with Ongoing Investigation." https:/www.sec.gov/news/press/2004-6.htm

7. 37 Am Jur 2d Fraud and Deceit $\S 1$. 
8. Silence when there is a duty to speak can also constitute making an untrue statement.

9. "Numbers manipulator describes Enron's descent." https://www.fraudmagazine.com/article.aspx?id=4294991880.

10. 26 Am Jur 2d Embezzlement $\S 1$.

11. Merriam-Webster. https://www.merriam-webster.com/dictionary/predict.

12. Skousen and Wright state, "the embezzler had the opportunity to perpetrate fraud" which of course is not possible. Embezzlers do not commit fraud.

13. Patent Number 6330546.

14. Predicate. https://www.dictionary.com/browse/predication

15. Minority Report was a science fiction novella written by Philip K. Dick published in 2002. It was later made into a movie starring Tom Cruise.

\section{REFERENCES}

ACFE. (2016). The fraud triangle. Retrieved from http://www.acfe.com/fraud-triangle.aspx

ACFE. (n.d.a.) What Is Fraud? Retrieved from https://www.acfe.com/fraud-101.aspx

ACFE. (n.d.b.). Analytics in compliance: Using predictive analytics to proactively identify compliance risks in transactions. Retrieved from https://www.fraud-magazine.com/wp.aspx?id=4295000597

AICPA. (2002). Consideration of fraud in a financial statement audit. Statement on Auditing Standards No. 99. New York: AICPA. Retrieved from https://www.aicpa.org/Research/Standards/AuditAttest/DownloadableDocuments/AU-00316.pdf

AICPA. (n.d.). Fraud and forensics classroom materials. Retrieved from https://www.aicpa.org/interestareas/accountingeducation/resources/classroommaterials/fraud.html

Albrecht, C.C. (n.d.). Fraud and forensic accounting in a digital environment. White Paper for the Institute for Fraud Prevention. Retrieved from https://silo.tips/download/fraud-and-forensicaccounting-in-a-digital-environment

Albrecht, W.S. (2014). Iconic fraud triangle endures: Metaphor diagram helps everybody understand fraud. Fraud Magazine. Retrieved from http://www.fraudmagazine.com/article.aspx?id=4294983342\&Site=ACFEWEB

Albrecht, W.S., Albrecht, C.O., Albrecht, C.C., \& Zimbelman, M.F. (2015). Fraud Examination (5th ed). Boston, MA: Cengage.

Baesens, B., Van Vlasselaer, V., \& Verbeke, W. (2015). Fraud analytics using descriptive, predictive, and social network techniques: A guide to data science for fraud detection. New York, NY: John Wiley \& Sons.

Bauguess, S.W. (2017, June 21). The role of big data, machine learning, and ai in assessing risks: A regulatory perspective. Retrieved from https://www.sec.gov/news/speech/bauguess-big-data-ai

Bell, T.B., \& Carcello, J.V. (2000). Research Notes, A decision aid for assessing the likelihood of fraudulent financial reporting. Auditing: A Journal of Theory and Practice, 19(1), 169-175. doi: 10.2308/aud.2000.19.1.169

Beneish, M.D. (1999, September/October). The detection of earnings manipulation. Financial Analysts Journal, pp. 24-36. doi:10.2469/faj.v55.n5.2296

Boyle, D.M., DeZoort, F.T., \& Hermanson, D.R. (2015). The effect of alternative fraud model use on auditors' fraud risk judgments. Journal of Accounting and Public Policy, 34(6), 578-596. doi: 10.1016/j.jaccpubpol.2015.05.006

Brazel, J.F., Jones, K.L., \& Zimbelman, M.F. (2009). Using nonfinancial measures to assess fraud risk. Journal of Accounting Research, 47(5), 1135-1166. doi: 10.1111/j.1475-679X.2009.00349.x

Cieslewicz, J.K. (2010). The fraud square: Societal influences on the risk of fraud. Paper presented at 2010 American Accounting Association Annual Meeting, 31 July-4 August 4, San Francisco.

Cieslewicz, J.K. (2012). The fraud model in international contexts: A call to include societal-level influences in the model. Journal of Forensic \& Investigative Accounting, 4(1), 214-254.

Retrieved from http://web.nacva.com/JFIA/Issues/JFIA-2012-1_8.pdf 
Cressey, D.R. (1953). Other people's money: A study in the social psychology of embezzlement. Glencoe, IL: Free Press.

Dechow, P.M., Ge, W., Larson, C.R., \& Sloan, R.G. (2011). Predicting material accounting misstatements. Contemporary Accounting Research, 28(1), 17-82. doi: 10.1111/j.19113846.2010.01041.x

Dorminey, J., Fleming, S., Kranacher, M., \& Riley, R. (2012). The evolution of fraud theory. Issues in Accounting Education, 27(2), 555-579. doi: 10.2308/iace-50131

Free, C., Macintosh, N., \& Stein, M. (2007). The organizational fraud triangle: Leadership, culture and control within Enron. Ivey Business Journal, 17(1), 1-8. Retrieved from

https://iveybusinessjournal.com/publication/management-controls-the-organizational-fraudtriangle-of-leadership-culture-and-control-in-enron/

Green, S. (2004). A look at the causes, impact and future of the Sarbanes-Oxley Act. Journal of International Business and Law, 3(1), 33-52.

http://scholarlycommons.law.hofstra.edu/jibl/vol3/iss $1 / 2$

Harris, J.T. (2015). Data analysis and reliability in predicting fraud. Forensics Journal: A Scholarly Review, 6, 57-64. Retrieved from https://www.stevenson.edu/online/publications/forensics/documents/forensic-journal-2015.pdf

Huber, W.D. (2017). Forensic accounting, fraud theory, and the end of the fraud triangle. Journal of Theoretical Accounting Research, 12(2), 28-48. Retrieved from https://papers.ssrn.com/sol3/papers.cfm?abstract_id=2423809

Indarto, S.L., \& Ghozali, I. (2016). Fraud diamond: Detection analysis on the fraudulent financial reporting. Risk Governance and Control: Financial Markets and Institution, 6(4), 116-124.

Kranacher, M.J., Riley, R.A., Jr., \& Wells, J.T. (2011). Forensic accounting and fraud examination. New York, NY: John Wiley \& Sons.

Lai, L., \& Khashu, S. (2015). Fraud detection and data analytics. In G. Pan, S.P. Sun, C. Chan, \& L.C. Yeong (Eds.), Analytics and cybersecurity: The shape of things to come (pp. 66-79). CPA Australia, Singapore Management University School of Accountancy and SIM University School of Business. Retrieved from https://www.cpaaustralia.com.au/ /media/corporate/allfiles/document/professionalresources/business/analytics-and-cybersecurity.pdf

Lee, C., Churyk, N.T., \& Clinton, B.C. (2013). Detect fraud before catastrophe: Proactive content analysis techniques can help management accountants prevent catastrophic financial fallout. Strategic Finance, 94(9). Retrieved from https://go.gale.com/ps/anonymous?id=GALE\%7CA323260180\&sid=googleScholar\&v=2.1\&it=r \&linkaccess $=$ abs\&issn $=1524833 \mathrm{X} \& \mathrm{p}=\mathrm{AONE} \& \mathrm{sw}=\mathrm{w}$

Manski, C.F. (2008). Identification for prediction and decision. Boston, MA: Harvard University Press.

Marks, J. (2012). The mind behind the fraudsters crime: Key behavioral and environmental elements. In ACFE Global Fraud Conference. Association of Certified Fraud Examiners. Retrieved from https://www.fraudconference.com/uploadedFiles/Fraud_Conference/Content/CourseMaterials/presentations/23rd/ppt/10C-Jonathan-Marks.pdf

Morales, J., Gendron, Y., \& Guénin-Paracini, H. (2014). The construction of the risky individual and vigilant organization: A genealogy of the fraud triangle. Accounting, Organizations and Society, 39(3), 170-194. doi: 10.1016/j.aos.2014.01.006

Omar, N., Johari, Z.A., \& Smith, M. (2017). Predicting fraudulent financial reporting using artificial neural network. Journal of Financial Crime, 24(2), 362-387. doi:10.1108/JFC-11-2015-0061

Pamungkas, I.D., \& Utomo, S.D. (2018). Fraudulent financial reporting: An application of fraud pentagon theory to association of Southeast Asian nations corporate governance scorecard. Journal of Advanced Research in Law and Economics, 5(35), 1729-1737.

Perols, J.L., Bowen, R.M., Zimmermann, C., \& Samba, B. (2017). Finding needles in a haystack: Using data analytics to improve fraud prediction. The Accounting Review, 92(2), 221-245. doi.org/10.2308/accr-51562 
Roden, D.M., Cox, S.R., \& Kim, J.L. 2016). The fraud triangle as a predictor of corporate fraud. Academy of Accounting and Financial Studies Journal, 20(1) 80-92. Retrieved from

https://www.researchgate.net/publication/304036915_The_Fraud_Triangle_as_a_Predictor_of_C orporate_Fraud

Ruankaew, T. (2016). Beyond the fraud diamond. International Journal of Business Management and Economic Research, 7(1), 474-476. Retrieved from Microsoft Word - 02 Beyond the Fraud Diamond (ijbmer.com).

Singleton, T.W., \& Singleton, A.J. (2010). Fraud Auditing and Forensic Accounting (4th Ed.) New York: Wiley.

Skousen, C.J., \& Wright, C.J. (2006). Contemporaneous risk factors and the prediction of financial statement fraud. Retrieved from http://papers.ssrn.com/sol3/papers.cfm?abstract_id=938736

Skousen, C.J., Smith, K.R., \& Wright, C.J. (2009). Detecting and predicting financial statement fraud: The effectiveness of the fraud triangle and SAS No. 99. In M. Hirschey, K. John, K., \& A.K. Makhija (Eds.), Corporate Governance and Firm Performance Advances in Financial Economics (Vol. 13, pp. 53-81). Emerald Group Publishing Limited, Bingley. doi: 10.1108/S15693732(2009)0000013005

Trompeter, G.M., Carpenter, T.D., Desai N., Jones, K.L., \& Riley, R.A., Jr. (2013). A synthesis of fraudrelated research. Auditing: A Journal of Practice \& Theory, 32(1), (Supplement), 287-321. doi: 10.2308/ajpt-50360

U.S. Patent Office. (2001). Risk determination and management using predictive modeling and transaction profiles for individual transacting entities. Retrieved from https://patents.justia.com/assignee/hnc-software-inc

Van Akkeren, J. (2018). Fraud triangle: Cressey's fraud triangle and alternative fraud theories. In D. Poff \& A. Michalos (Eds.), Encyclopedia of Business and Professional Ethics. New York: Springer. doi:10.1007/978-3-319-23514-1_216

Wolfe, D.T., \& Hermanson, D.R. (2004). The fraud diamond: Considering the four elements of fraud. The CPA Journal, 74(12), 38-42. Retrieved from https://digitalcommons.kennesaw.edu/facpubs/1537/ 